\title{
Polishing the Thinking on the Role of Open and Distance Learning in Socio-Economic Development: Exposing the Missing Functions of Higher Education
}

\author{
Prof. Mupa Paul \\ Zimbabwe Open University,E-mail:mupapaul@gmail.com \\ Prof. Chabaya Owence \\ University of Limpopo,E-mail:chabayaowence@gmail.com/Owence.chabaya@ul.ac.za \\ Prof. Chabaya Raphinos Alexander \\ Zimbabwe Open University Regional Campus Director \\ E-mail:raphinoschabaya@gmail.com
}

Doi:10.5901/mjss.2014.v5n11p177

\begin{abstract}
Open and Distance Learning universities have a missing mission if they fail to provide socio-economic development to all of society. Higher education is considered as the panacea to socio-economic development by nations, the world over. It brings to the individual mental treasure, knowledge and skills that are useful in the development of a country and hence, it is the bedrock to socio-economic development. The philosophy of ODL which include, among others, access, flexibility and free choice by learners is its competitive advantage and is the centrepiece of societal improvement. For socio-economic development to be achieved, large numbers of people in society, including women, have to be highly educated so as to capacitate them with knowledge of high standards of health, disease prevention, participation in political and economic activities, farming, selfreliance skills, among other things. ODL meets this role of equipping society with higher education knowledge and skills which are requisite for socio-economic development.
\end{abstract}

Keywords: socio-economic development; Higher education; Open and Distance Learning

\section{Background}

The role that Open and Distance Learning (ODL) plays in socio-economic development is a missing headline in today's media. The provision of ODL can influence the socio-economic development of society in many ways. History has it that Zimbabweans were highly marginalised in terms of access to higher education. The education that was offered was for subservience so that the blacks would be good boys for the white colonial masters. The only university that existed before and soon after independence in Zimbabwe was the University of Zimbabwe and it enrolled only a few students. In 1982, the University of Zimbabwe Act had the objective of providing correspondence courses and extramural courses for young persons and adults (University of Zimbabwe Act, 1982). From a scholarly view point, we notice that the university was taking the direction of extending university education through distance education. This policy had a bearing on the birth of Open and Distance Learning in Zimbabwe. The traditional way to attain higher education had barriers in terms of access and affordability. Faced with such a scenario which required higher education for economic development, it was necessary for the Zimbabwean government to introduce Open and Distance learning in order to take education to the door steps of everyone and empower them. In 1994, the University of Zimbabwe opened a Centre for Distance Education and spread it throughout the ten regions of Zimbabwe. This culminated to the official launching of the Zimbabwe Open University in 1999. The Open and Distance Learning (ODL) mode of education allows access by one and all regardless of class, race or age. It is affordable and therefore, capable of empowering the vast majority of people in all forms of circumstances. ODL is a dynamic force in empowering all segments of society with higher education since its inception in Zimbabwe. Its philosophy of access, flexibility, anytime, anywhere, has moved individuals and all people towards the light of empowerment. Economic development has been the answer.

According to the International Commission on Education for the 21st Century (1998, p. 206), most African countries can boast of less than 1 per cent of the relevant age-group attaining any form of tertiary education. It is also argued that enrollment rates in higher education in Sub-Saharan Africa are by far the lowest in the world (The Task Force 
on Higher Education and Society, 2000). In a speech, UN Secretary General Kofi Annan argued:

The university must become a primary tool for Africa's development in the new century. Universities can help develop African expertise; they can enhance the analysis of African problems; strengthen domestic institutions; serve as a model environment for the practice of good governance, conflict resolution and respect for human rights, and enable African academics to play an active part in the global community of scholars (United Nations Information Service, 2000).

With few individuals accessing university education, it is not easy for Africa to reach greater heights in terms of socio-economic development. One can question how nations can manufacture knowledge for socio-economic development in such kind of scenario. Universities are considered as the engines of the knowledge economy and thus the source of knowledge for socio-economic development in nations. Open and Distance Learning universities have a missing mission if they fail to provide socio-economic development to all of society. Higher education is considered as the panacea to socio-economic development by nations, the world over. It brings to the individual knowledge and skills that are useful in the development of any country, hence, it is the panacea to socio-economic development. Education is the key to empowerment of all segments of society and its scarcity is a blow to the social order of society. The conventional system of education has always failed to meet this demand because of its limited facilities and equipment. The traditional trend of attaching entry strings into higher education has been challenged by the coming in of Open and Distance Learning where opportunities are provided. Nations have realised the role that ODL can play in terms of bringing about socio-economic development. To this end, ODL policies have been instituted for the provision of higher education through ODL, with the learner centred approaches. ODL can be used as a vehicle for delivering Higher Education and Training and this can in turn, accelerate socio-economic development and reduce unemployment rates in the country. ODL aims at upgrading the skills and knowledge of existing workforce by increasing its actual productivity and thus create human capital which is competitive in the globalisation process and trade liberalisation. There is increasing emphasis on the importance of higher education institutions for sustainable development, particularly ODL, because of their importance to the global knowledge economy. It is argued that:

The most important economic development of our lifetime has been the rise of a new system for creating wealth, based no longer on muscle but on mind (Toffler as cited in George, 2006, p. 590).

The development of the mind is pointed to as the basis for socio-economic development. Literacy and numeracy are the basic skills that are provided by exposure to primary and secondary education. Higher education goes further to create wealth for the nations by equipping individuals with mental muscles that develop the economy. The argument advanced for this thinking is that Higher Education brings with it some intellectual treasure to the individual, which then can be used for the development of the country. Higher education therefore, is considered to be the key to the continuous growth of economies. The core business of Higher education is investment in knowledge which means investment in areas that generate knowledge, such as research and development, software, education and basic science. The philosophy underlying the establishment of ODL is that of providing human resource with knowledge and skills that can uplift the nations by virtue of the flexibility of the learning mode. ODL allows individuals to work while they learn. This means that the workforce is not disrupted and production does not drop. The workforce pursues degrees in specific areas related to their work and this sharpens their knowledge and skills of their jobs while at their jobs. If knowledge of the job is a necessary condition for take-off to socio-economic development of a country, therefore, ODL learners begin to develop the nation soon after enrolling as students because they start practising what they are learning forthwith.

ODL universities stand for the improvement, empowerment and forward march of the human race towards socioeconomic development. They are the drivers to socio-economic development. Some of the unique features of Open and Distance Learning the world over are huge student population, the rapid growth of ICT use and globalisation. All these features contribute to the development of nations. The high number of student enrolment is a clear indicator of the number of people who equipped with knowledge and skills that can be used for socio-economic development. The existence of quality assurance mechanisms in the ODL system is a clear indication of the zero defect higher education provided by the system.

\section{Statement of the Problem}

There are many potential students out of higher education institutions in most developing countries including Zimbabwe. The provision of ODL is minimal due to lack of polished thinking. Some people feel that ODL plays a minimal role in socio-economic development and yet it is the panacea to the provision of university education to all. Higher education, if confined to conventional systems alone, has a missing function of developing the mental capacity of the majority of potential degree holders due to limited access. Conventional systems are failing to meet the demand for providing higher education yet it is through attaining university education that nations bring about socio-economic development. ODL has 
vast potential of bringing about socio-economic development in many countries with millions of aspirants eager to receive higher education and with conventional universities simply not being in a position to accommodate them.

\section{Main Research Question}

To What Extent Does ODL Contribute Towards Socio-Economic Development?

\section{Research questions}

1. How far does ODL contribute towards socio-economic development?

2. What is the role of ODL in enhancing socio-economic development?

3. What are the missing functions of higher education in socio-economic development?

\section{Conceptual framework}

\subsection{What is Open and Distance Learning (ODL)?}

Open and Distance Learning is defined by the Commonwealth of Learning as a way of providing learning opportunities that is characterised by the separation of teacher and learner in time or place, or both time and place; learning that is certified in some way by an institution or agency; the use of a variety of media, including print and electronic; two-way communication that allows learners and tutors to interact; the possibility of occasional face-to-face meetings; and a specialised division of labour in the production and delivery of courses (The Commonwealth of Learning, 2000).

ODL is a type of educational mode that allows for flexibility in terms of mode and delivery. It is the combination of on-line learning (e-learning) and other distance education delivery methods that include the print media. In a very modern sense, it is the introduction, utilisation and application of ICT to enhance open and distance education, thus implementing open and distance learning policies in order to make learning activities more flexible and enable these learning activities to be distributed among many learning venues. It is an amalgam of two approaches to different forms of education that focus on expanding access to learning. It is a sort of blended and distributed learning, which incorporate elements of tutor mediated and self-directed and resource-based learning process. It is a shift from the pedagogical face-to-face traditional way of teaching or even the traditional distance education (called correspondence education) to learner centred pedagogies. It is argued that this type of education is characterised by two factors, that is, its philosophy and its use of technology. ODL philosophy aims at removing barriers to education, allowing students to study what they want, when they want and where they want. In summing up the Open and Distance Learning philosophy, it aims at increasing educational access and increasing educational choice to students (Olu, Omolara and Theodore, 2011).

\section{Theoretical Framework}

This research was guided by the human capital theory of development. There is a general consensus that human capital plays a substantial role in achieving higher economic growth and increased labour productivity for a country. The human capital approach arose from an acknowledgment that an individual or nation's decision to invest in human capital is similar to any other investment. Investment in human capital is done with the hope of making individuals value-added and become more productive. The human capital can exert a sustained and positive effect on the long-term growth of the economy. It is argued that human capital is a major determinant of economic growth and productivity in a global environment (Benjamin, Marathamuthu, Muthaiyah and Raman, 2011).

\section{Literature}

\subsection{How Does Socio-Economic Development Come about in a Country?}

The significance of tertiary education to the nation's well-being is acknowledged by all countries (Centre for Policy Studies, 2005). It is argued that the question of the cost, accessibility and the affordability of tertiary education to the average and low-earning groups are crucial as it is instrumental for a country to achieve socio-economic goals (Benjamin, et al, 2011). This clearly shows that if education is made accessible, available and affordable, many people can access it and a society with higher education is on the road to socio-economic development. In Plato's view, the fundamental 
purpose of education is to select and train men and women according to merit for the various duties and functions of society (Barker, 1991, p. 22). As such, education should lead a person from the cave of ignorance to the limelight of knowledge. Knowledge that brings about socio-economic development is mainly gained through university exposure and lack of such exposure is doomed as a recipe for low development in society. Plato's content of higher education was as such to aid abstract reasoning and this consisted of mathematics, astronomy, dialectic and philosophy. This kind of curriculum is not enough for the present century but what it entails is that higher education curriculum exposes individuals to knowledge creation and thus socio-economic development.

The achievement of Millennium Development Goals (MDGs) is central in achieving the socio-economic development agenda. ODL closes the missing functions of higher education by ensuring that creative and innovative activities are generated in the local environments in a bid to bring about socio-economic development in their localities (World Bank, 2002).. MDGs are the centrepiece of socio-economic development for any nation and their achievement is only possible if there is a knowledgeable and skilled workforce whose mental capabilities have been sharpened through the higher education discourse and milieu. In its mission, ODL provides knowledge through learner centred methodologies which give its practitioners the ability to carry out empirical research in their localities on how best to achieve the goals. The achievement of MDGs is a cause for concern as regards socio-economic development.

MDG 1 - Eradicate extreme poverty and hunger

MDG 2 - Achieve universal primary education

MDG 3 - Promote gender equality and empower women

MDG 4 - Reduce child mortality

MDG 5 - Improve maternal health

MDG-6 - combat HIV and AIDS, malaria and other diseases

Tertiary education institutions support knowledge-driven economic growth strategies and poverty reduction by (a) training a qualified and adaptable labour force (b) generating new knowledge; and (c) building the capacity to access existing stores of global knowledge and to adapt that knowledge to local use. Tertiary education institutions are unique in their ability to integrate and create synergy among these three dimensions. The norms, values, attitudes, ethics, and knowledge that tertiary institutions can impart to students constitute the social capital necessary to construct healthy civil societies and socially cohesive cultures (World Bank, 2002). In a knowledge-based global economy the emphasis must be not only on the structure of educational institutions, but also on their content (George, 2006). It is argued that for the future, the most important skill that education can supply is flexibility (Riddell, 1996). ODL students stay in their soil and thus contribute to local economic development. The student does not only get polished thinking form the system but is also made responsible for the adaptation of internationally available knowledge for local consumption.

Studies in Australia, for example, have established that higher education attainment translates directly into higher productivity, higher standards of health care and public welfare. In their study, Chou (2003, p. 397) found that 42 percent of Australian growth between 1960 and 2000 is attributable to the rise in the attainment of higher education. As such, it becomes critical to ensure the provision of higher education to all who need it in order to bring about socioeconomic development to society.

\subsection{The Role of ODL in Socio-Economic Development}

According to Mehrotra, Hollister, and McGahey as cited in Chaney, Eddy, Dorman, Glessner, Green and Lara-Alecio (2009), ODL is not a future possibility for which higher education must prepare, it is a current reality creating opportunities for educational institutions; a reality offering students expanded choices in where, when, how, and from whom they learn; a reality making education accessible to ever larger numbers of persons. It is argued that Open and distance learning is among the many methods of delivery that can have a larger role in meeting the needs of the tertiary sector (Ansari, 1994). The idea of educating larger numbers of the society's segment should be upheld. For socio-economic development to take place, there is need to have large groups of people participating in the economic affairs and income generation projects in the society. The role of ODL is therefore to open up higher education opportunities to large segments of the society and thus contribute to the socio-economic development of the nation. Because educated people are, on the average, quicker to train and adopt new technologies, they tend to be the innovators in a country.

One of the United Nations Development Programme's (UNDP's) measure of development of nations is gender equity (MDG 3). Education, especially tertiary education, is more likely to break down traditional barriers and therefore make it possible to increase women's participation in national politics (Gyimah-Brempong, 2011). Due to the flexibility of $\mathrm{ODL}$, quite a number of women can participate in higher education without compromising their routine duties in the family and work environment. ODL therefore provides the role of opening up opportunities for marginalised groups and lift up 
their standards of living.

Socio-economic development arises in society when there is decrease in disease among members. The sustained prevalence of the HIV and AIDS pandemic is cause for concern globally. The philosophy of ODL is that education should be made accessible to all those who need it and should be brought to the door steps of every individual. It is argued that further education tends to have positive effects on health outcomes (Silles, 2009). The trend is that educated people have better information about health alternatives or they make better health decisions and are less likely to be misinformed about HIV and AIDS in society. Highly educated people are able to choose better health inputs which in turn increase their health outcomes and diet than those with lower levels of education. Most educated people vested interest to invest in their health in order to higher earnings. It is argued that at low levels of education, education and HIV and AIDS are positively correlated but the correlation turns negative at higher levels of education (Fortson, 2008).

\section{Research Methodology}

This research was grounded in the interpretivist philosophy. The qualitative methodology was employed. This was a case study design which looked at Open and Distance Learning Universities only to see how they contribute towards socioeconomic development in society. It employed semi-structured interviews and personal accounts for data generation. Purposive sampling was used to select the participants who were ODL graduates in various walks of life. The researchers identified products of Open and Distance Learning occupying high positions in society and booked for interviews with them. The participants were willing to take part in the research and ready to be interviewed.

\section{Data Analysis}

For data analysis, the researchers used the thematic approach. Basit (2003, p. 143) describes the analysis of qualitative data as being a difficult, dynamic, intuitive, and creative process, the aim of which is to determine the assumptions, categories, and relationships that inform participants' views of the world in general and of the issue under investigation in particular (McCracken, 1988). This involves "working with data, organising it, breaking it into manageable units, synthesising it, searching for patterns, discovering what is important and what is to be learned, and deciding what you will tell others" (Bogdan \& Biklen, 1982, p. 145). It allows research findings to be drawn from the dominant or significant themes teased from the raw data without the constraints of more structured methodologies (Thomas, 2003). The primary goal is to generate understanding of the participants' sense making in the research situation.

\section{Results}

\subsection{ODL Gives Access to All Who Need University Education for Socio-Economic Development}

Participants had this to say:

The provision of higher education to the majority of people in a country is the route to socio-economic development. $O D L$ is doing justice in terms of providing higher education to many segments of society. Through the ODL mode of learning, many people are getting access to higher education and this enables them to participate fully in the realms of political and economic activities fully. Many sectors of the economy including women have been empowered through ODL in Zimbabwe. Politicians, industry and commerce, the civil service, non-government organisations and the private sector are benefiting from the ODL project.

There is always an argument advanced for the provision of tertiary education by nations in their development agendas. The World Bank report has this to say:

Tertiary education is a 'critical pillar for human development' ... [that] provides not only the high-level skills necessary for every labour market, but also the training essential for teachers, doctors, nurses, civil servants, engineers, humanists, entrepreneurs, scientists, social scientists, and myriad personnel. It is these trained individuals who develop the capacity and analytical skills that drive local economies, support civil society, teach children, lead effective governments, and make important decisions which affect entire societies (World Bank, 2002: 10)

\subsection{Women Have Been Empowered a Lot}

Participants raised that ODL promotes women advancement and they have risen to high positions in society as a result of 
that. They had this to say:

ODL has given women the chance to reach the unreached. You know what! A lot of women who never had the chance to get to university have attained degrees from the ODL system. Remember their place before independence in Zimbabwe was in the home. Soon after independence, several women had no opportunities to further their studies particularly at university level. Yes, work policies were improved on their favour but the gap remained in terms of reaching the unreached. These women are now school leaders, provincial directors, school inspectors, managers in companies, among others. They could not have had attained such high positions in the echelons of society had it not been the ODL project.

It is argued that for socio-economic development to take place, the involvement of all segments of society is crucial. Participation by women in economic issues of any given society is a precondition for take-off to socio-economic development.

\subsection{ODL Has Been used to Combat Hiv and Aids in Countries with High Dropout Rates and High Orphanage}

Participants raised a very important contribution that is made by ODL. They had this to say:

One major mandate for higher education is to carry out research to solve problems that affect society. The researches that are done by ODL researchers have become part of the solutions to solving issues like poverty, HIV and AIDS prevalence among society. It is the role of ODL to combat HIV and AIDS. A lot of research work has been done in the prevention of the pandemic. In countries like South Africa and Mozambique where there is high dropout rate from school, ODL has managed to educate the school leavers the impact of the pandemic and poverty reduction strategies. ODL addresses HIV and AIDS using a framework that emphasises poverty.

Research argues that ODL can be used to deliver the national curriculum more flexibly, so that young people do not have to fall behind with their HIV and AIDS lessons when they cannot attend school and can more easily re-enter schooling if they have dropped out. In Mozambique, the UNESCO proposal to use Radio Mozambique to deliver the new national school curriculum has enormous potential to fill a gap of combating HIV and AIDS. AIDS is recognised as an emergency threatening development, social cohesion, political stability, food security, life expectancy, and economic growth.3 Experience has shown that HIV and AIDS can affect young people economically, educationally, and psychosocially (Pridmore and Yates, 2005).

\subsection{ODL is Opening Up New Avenues in the Higher Education Landscape}

Participants had the following to say:

The academic programmes offered by ODL universities particularly the Zimbabwe Open University and its mode of study are opening up new opportunities for higher education in areas not previously served by the other universities. There are degrees in Educational Leadership and Management, Nursing Science, among others, which were never offered by the conventional universities. These and the many others degrees offered are pillars in the circles of socioeconomic development. ZOU reaches learners at their door steps through the regional centres and this means higher level of access by the prospective learners. Access to higher education is the driver of change in most societies because one is empowered to do many things through knowledge gained.

\subsection{Courses Offered by ZOU are Improving the Status of the Business Community}

One participant had this to say:

E-e-e, You know what, most business operations have improved as a result of the Zimbabwe Open University commerce degrees obtained by business people. These people suffered lack of education before the inception of ODL in the higher education landscape in Zimbabwe. They could not leave their businesses going to conventional systems which had a lot of strings in terms of entrance. Their mission of gaining knowledge in operating Small Scale Businesses (SMEs) has been accomplished. Today, it is this kind of activity that is sustaining the economy of the country. Outside employing themselves, SMEs have employed quite a number of school leavers and these people are earning a living from it. This is a direct benefit to the society and to the government as well.

It is argued that successful entrepreneurs need to be very efficient in maintaining their competitive knowledge base 
(Gray, 2006). Efficiency is obtained by means of gaining knowledge relevant to one's field of operation. If entrepreneurs fail to get knowledge of how to operate their businesses from higher education, then they are likely to close the shops and go home. Hughes, Keddie, Webb and Corney (2002) argue that in a fast-changing world of work, the ability to adapt and develop new learning and skills is a crucial ingredient in a successful economy. Globalisation and the knowledge-driven economy require the higher education sector to develop a more highly-skilled workforce in order to compete within highvalue-added sectors of the world economy.

\title{
10.6 ODL Graduates are Manning many Sectors of the Economy
}

Participants pointed out that ODL graduates seem to be dominating in most, if not all sectors of the economy. One participant had this to say:

\begin{abstract}
Let me share with you that the products of the ODL system here in Zimbabwe are manning most sectors of the economy. There are various ministries where you find the ODL graduates contributing effectively as Provincial Directors of Education, ministers, university lecturers, school heads, Agricultural officers, development officers, Public Service Inspectors, you name it. These have become the pillars of socio-economic development in the Zimbabwean society.
\end{abstract}

Higher education opportunities are considered as the gateway to high paying jobs and as the source of improved knowledge and skills for workers. It is argued that the expansion of educational opportunities at all levels has contributed to aggregate economic growth by creating a more productive labour force and endowing it with increased knowledge and skills, providing widespread employment and income earning opportunities (Todaro, 1992).

\subsection{ODL is Eliminating Various Forms of Poverty from Society}

Participants noted that ODL has gone very far in eliminating various forms of poverty from society in the Zimbabwean context. They had this to say:

$O D L$ is bringing sanity and normalising the historical imbalances that existed before independence in Zimbabwe in terms of education provision. By so doing, it is proving effective in eliminating various forms of poverty.

Poverty is highly correlated with social exclusion, marginalisation, vulnerability, powerlessness, isolation and other economic, political, social and cultural dimensions of deprivation. In addition to low income, poverty is reflected in malnutrition, poor health, low literacy levels, inadequate clothing, shelter and living conditions. It results from limited access to basic infrastructure and services, land, credit, technology and institutions and other productive assets and resources needed to ensure sustainable livelihoods. It is symptom of imbedded structural imbalances which manifest themselves in all domains of society (Hamdock, 1999, p. 293-294).

\section{Conclusions}

There are quite a number of conclusions emanating from this study. ODL as a form of higher education provision is proving useful in the contributing towards socio-economic development particularly in Zimbabwe. Most sectors of the economy including the Public Service, Ministry of Primary and Secondary Education, Ministry of Higher Education, Commerce and Industry, Agriculture, among others, are manned by ODL graduates. Higher education knowledge sharpens the skills and competencies of workers and they become more efficient and effective at workplaces. For a nation to reach to high levels of socio-economic development, it has to provide higher education to large numbers of people. ODL is the answer to such provisions in the light of paucity of resources and facilities caused by economic backdrops in many countries. The study also concludes that ODL contributes to socio-economic development through the courses and programmes that fight against disease, poverty and malnutrition. Business people, who could not have had the chance to attain higher education, are gaining entrepreneurship knowledge and skills to effectively run their businesses.

\section{Recommendations}

In the light of the above conclusions, the following recommendations were made:

- Governments should ensure the provision of ODL in order to increase access to higher education. 
- Governments should set aside a budget to support the smooth running of ODL systems.

- The provision of grants and loans as learner support services should also extent to ODL students since the products of the system also contribute towards socio-economic development.

- Donor agencies should come in to support students in the ODL system since they will eventually contribute to socio-economic development.

- Employers should consider providing employment opportunities to ODL graduates to facilitate quick socioeconomic development of nations.

\section{References}

Ansari, M. (1994). Economics of distance education in India. In Economics of distance education: Recent experience, ed. G. Dhanarajan, P.K. Ip, K.S. Yuen, and C. Swales, 74-87. Hong Kong: Open Learning Institute Press.

Barker, R. (1991). Philosophies of Education. Harare, The College Press.

Basit, T. N. (2003). Manual or electronic? The role of coding in qualitative data analysis. Educational Research, 45, 143-154.

Benjamin, S. J. M. Marathamuthu, S., Muthaiyah, S. and Raman, M. (2011) Affordability of private tertiary education: a Malaysian study. International Journal of Social Economics Vol. 38 No. 4, pp. 382-406.

Bogdan, R. C., \& Biklen, S. K. (1982). Qualitative research for education: An introduction to theory and methods. Boston, MA: Allyn \& Bacon.

Centre for Public Policy Studies (2005), Achieving Higher Performance in Tertiary Education, available at: www.cpps.org.my/sub_page.aspx?catID1/46\&ddID1/4354 (accessed October 1, 2008).

Chaney, B. H., Eddy, J. M., Dorman, S. M., Glessner, L. L., Green, B. L. and Lara-Alecio, R. (2009) A Primer on Quality Indicators of Distance Education. Health Promotion Practice. 10: 222 SAGE Publications.

Chou, Y. K. (2003), "The Australian growth experience, 1960-2000: human capital, R\&D or steady-state growth?", Australian Economic Review, Vol. 36, pp. 397-414.

Fortson, J.G. (2008), 'The Gradient in Sub-Saharan Africa: Socioeconomic Status and HIVIAIDS', Demography, Vol. 45, No. 2, pp. 30322.

George, E. (2006) Positioning higher education for the knowledge based economy. Higher Education: 52: 589-610.

Gray, C. (2006),"Absorptive capacity, knowledge management and innovation in entrepreneurial small firms", International Journal of Entrepreneurial Behaviour \& Research, Vol. 12 Iss: 6 pp. $345-360$.

Gyimah-Brempong, K. (2011). Education and Economic Development in Africa. African Development Review, Vol. 23, No. 2, 219-236.

Hamdock, A.A. (1999). A Poverty Assessment Exercise in Zimbabwe. African Development Bank, Blackwell Publishers.

Hughes, M., Keddie, A., Webb, P. and Corney, M. (2002), Working Towards Skills Perspectives on Workforce Development, Learning and Skills Development Agency (LSDA), London.

International Commission on Education for the Twenty-First Century (1998) Learning: The Treasure Within. United Nations Educational, Scientific and Cultural Organization, Paris, 1998.

McCracken, G. (1988). The long interview. Sage University paper series on qualitative research methods. (Vol. 13). Newbury Park, CA: Sage.

Olu, A., Omolara, D. and Theodore, I. (2011) Analytical studies of various marketing approaches that could assist the growth of educational programmes of the Open and Distance Learning institutions. International Journal of Academic Research Vol. 3. No. 3. Part 11.

Pridmore, P. and Yates, C. (2005) Combating AIDS in South Africa and Mozambique: The Role of Open, Distance, and Flexible Learning (ODFL). Comparative Education Review, Vol. 49, No. 4, Special Issue on Education and Public Health: Mutual Challenges Worldwide<break></break>Guest Editor: David E. Bloom, pp. 490-511.

Riddell, A. (1996). 'Globalisation: Emasculation or opportunity for educational planning?' World Development 24(8), 1357-1372.

Silles, M. (2009), 'The Causal Effect of Education on Health: Evidence from the United Kingdom', Economics of Education Review, Vol. 28, No. 1, pp. 122-28.

The Commonwealth of Learning (2000). "An Introduction to Open and Distance Learning." http://www.col.org/colweb/webdav/site/ myjahiasite/shared/docs/ODLIntro.pdf.

The Task Force on Higher Education and Society (2000), Higher Education in Developing Countries: Peril and Promise. Washington DC, World Bank.

Todaro, M. P. (1999). Economics for a Developng World: An introduction to principles, problems and policies for development. London, Longman.

Thomas, D. R. (2003). A general inductive approach for qualitative data analysis. Paper presented at School of Population Health, University of Auckland, New Zealand, August.

University of Zimbabwe Act (1982) Chapter 25:16, 4 (d), Harare, Zimbabwe.

United Nations Information Service (2000): "Information Technology Should be Used to Tap Knowledge from Greatest Universities to Bring Learning to All, Kofi Annan Says." Press Release No: UNIS/SG/2625. August 3, 2000. Internet: www.unis.unvienna.org/unis/pressrels/2000/sg2625.html (Last accessed: May 6, 2005).

World Bank, (2002). Constructing Knowledge Societies: New challenges for tertiary education. Washington D.C: World Bank. 